\title{
Seismic Vulnerability Assessment of Reinforced Concrete Building Structures in Erbil City, Capital City of Kurdistan Region of Iraq
}

\author{
Zina A. Abduljaleel ${ }^{1} \&$ Bahman O. Taha ${ }^{2} \&$ Abdulhammed A. Yaseen ${ }^{3}$ \\ ${ }^{1}$ Department of Technical Civil Engineering, Technical College of Engineering, Erbil Polytechnic \\ University, Iraq \\ ${ }^{2}$ Department of Technical Civil Engineering, Technical College of Engineering, Erbil Polytechnic \\ University, Iraq \\ ${ }^{3}$ Department of Civil Engineering, College of Engineering, University of Duhok, Iraq \\ Correspondence: Bahman O. Taha, Erbil Polytechnic University, Iraq. \\ Email: bahman.taha@epu.edu.iq
}

Doi: 10.23918/eajse.v6i1p161

\begin{abstract}
Rapid developments in Erbil city along with repeated seismic activity have caused concern about the safety of reference building structures. The reference buildings might be at risk since constructed with a misunderstanding about the seismicity and without seismic code regulations. Consequently, seismic vulnerability assessment of reference building structures has been conducted which is representing contemporary buildings including commercial, hotel, and residential building, by employing detailed archetypes in finite-based modelling. Inelastic pushover and over 800 incremental dynamic analyses are performed to evaluate seismic vulnerability for the selected reference structures so that the actual response analysed with studying the influences regarding the presence of infilling masonry panels. It was concluded that the selected reference buildings are significantly vulnerable under expected seismic. It was demonstrated that there is an urgent need for seismic retrofit and strengthening for the reference building structures to reduce their seismic losses.
\end{abstract}

Keywords: Erbil, Incremental Dynamic Analysis, Inelastic Pushover, Vulnerability Assessment

\section{Introduction}

Erbil governorate frequently experiences small to moderate earthquakes. On July 24, 1991, the moderate magnitude of 5.5 earthquake struck Erbil city (IMOS, 2018). More recently, the activity of the Zagros fault has been increased significantly. Consequently, the recommended design Peak Ground Acceleration (PGA) in Erbil city is identified by value $0.25 \mathrm{~g}$ and $0.4 \mathrm{~g}$ on bedrock for return periods of 475 and 2475, respectively (AbdulJaleel \& Taha, 2019). The collapses of building structures during recent earthquakes, especially, in the northern and eastern of Greater Kurdistan (e.g. Van earthquake in 2011; Iran-Iraq border earthquake near Halabja in 2017; Elazig and Malatya earthquake in 2020), furthermore, rapid developments in Erbil city along with repeated seismic activity have caused concern about the safety of existing building structures. The analysis of exposure indicated that the minor types of construction in Erbil city are reinforced concrete (CSO, 2011; KRSO, 2018) and the databases of the municipality management also indicated that the buildings designed only for gravity load (Presidency of Erbil Municipality, 2012). Therefore, the building stock inventory in Erbil city might be vulnerable and experience a high risk of damage, these buildings generally experience low levels of strength and ductility since they constructed with a misunderstanding about the seismicity and without seismic code regulations. Recent studies underlined the necessity of evaluating the vulnerability of pre-seismic code buildings, and the urgent need to decrease their seismic losses (e.g. Bruno et al. (2000) in Sicily-South of Italy, Cosenza et al. (2000) in Catania-South of Italy, Ismaeil (2018) in Sudan, Issa and Mwafy (2014) in UAE, and Occhipinti et al. (2017) in Catania-South of Italy). Poor performance of pre-seismic code buildings will prohibit those structures to achieve the required seismic performance target (ASCE/SEI 41-13, 
2014; ATC, 2011). Thus, this study centers on the seismic vulnerability of contemporary reference $\mathrm{RC}$ building structures in Erbil city, by considering the actual response (e.g. presence of infill walls and possible irregularity in vertical and horizontal). To performing the seismic vulnerability assessment, the following information and data are necessary:

1) survey of the building stock inventory; 2) selecting typical buildings to represent RC building stock and obtaining their plans of construction; 3) review of the seismic characteristics and consequently selection of real ground-motion records; and 4) modeling finite-based model and analyzing.

\section{Building Stock Inventory}

\subsection{Database of the Existing Building Structures}

The first component for developing the earthquake loss estimation system is identifying the building stock databases for the study area. Erbil city has a population of approximately nine hundred thousand people (CSO, 2011; KRSO, 2018). According to the Central Statistical Organization (CSO, 2011), Erbil city stock consists of approximately 156,274 buildings, while updated data approximately 15,300 added buildings are reported in 2014 (KRSO, 2018). According to CSO, the buildings classified by type; occupancy; age of the buildings; construction material; and the number of floors, as shown in Figure $1 \mathrm{a}, \mathrm{b}$, and c. Eighty percent of the buildings consist of dwellings, whereas $20 \%$ of the buildings are used for other purposes. Seventy-nine point zero five percent of the buildings are conventional buildings (e.g. house and attached buildings), $0.34 \%$ of the buildings comprise mobile or marginal types of buildings (e.g. hut, tent, and caravan), and $20.61 \%$ of the buildings include other buildings (e.g. institution and shopping center). The construction rate of multi-story buildings (more than three floors) increased after 2000. Concrete blocks are the major material used in the construction of conventional and other building types. Census data has not been updated for ten years, therefore, municipality (Mun) documentation data also utilized. Mun data in Erbil city documented about 2890 buildings with a height of more than three floors, Mun data utilized to classify the contemporary buildings by the distribution of the buildings on the Mun; age after 2000; and the number of floors as shown in Figure $1 \mathrm{~d}$, e, and f. Most of the buildings have three and four floors located in the Mun one. Most of the buildings in Mun have been utilized for commercial purposes and classified by risk category ASCE-II. After 2010, the construction rate of the buildings increased to roughly half percent and the skyscrapers have been constructed. The following seismic codes are established concerning the building construction year:

1) Iraq seismic code in 1988, 2) Iraq seismic code in 1997, 3) After more than fifteen years outdated, the new Iraqi draft in 2016. Building stocks in Erbil city were designed primarily for gravity loads, nevertheless, some of the buildings were designed for seismic load related to UBC 1997. 


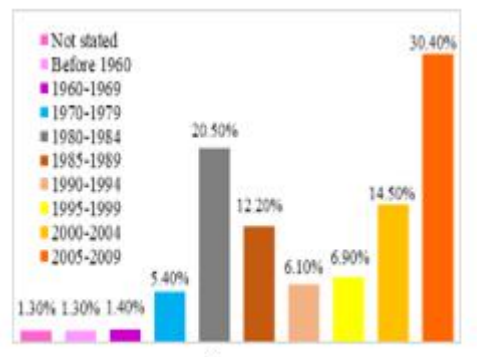

a)

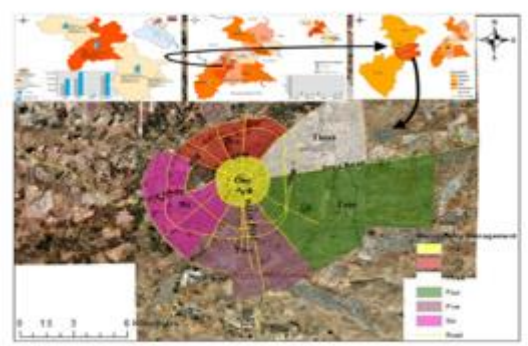

d)

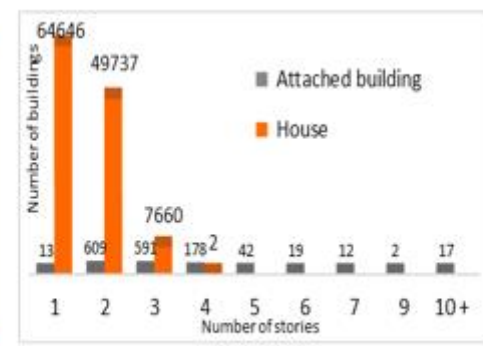

b)

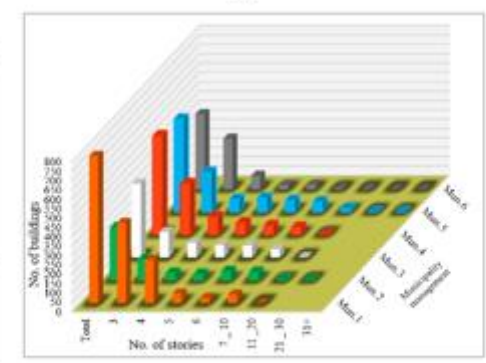

e)

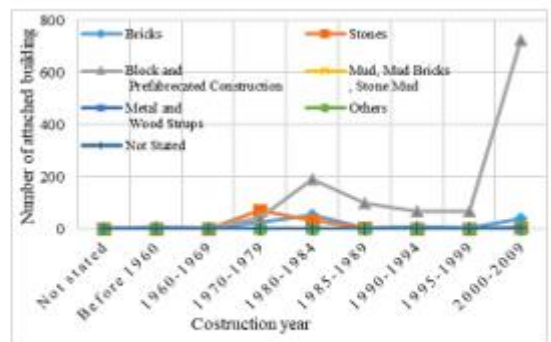

$-1$

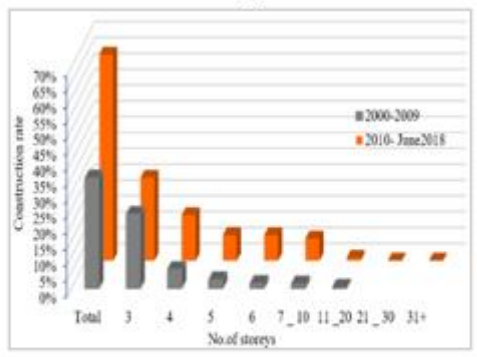

f)

Figure 1: Graphical description of the building stock a) CSO by age, b) CSO by number of floors c) CSO by construction material d) Mun managements e) Mun by number of floors e) Mun by age

\subsection{Selection of Existing Building Structures}

According to the Mun database, three reference RC buildings representing modern buildings of 6,9 , and 11 stories, were selected for the current study. Selected buildings described by the real function such as Commercial building (COML-06), Hotel building (HB-09), and Residential building (RB11). Figure 2 shows the selected buildings from Erbil city to represent reference buildings, while Table 1 summarizes the characteristics of the selected buildings. Moreover, selected buildings have a basement floor, COML-06 has three typical story height of $3.42 \mathrm{~m}$, while RB-11 has the same height of $3 \mathrm{~m}$, and HB-09 comprises eight typical story height of $3.6 \mathrm{~m}$.

Table 1: Summary of the selected buildings

\begin{tabular}{|c|c|c|c|c|c|c|c|c|c|c|c|}
\hline \multirow[b]{2}{*}{ 号 } & \multirow[b]{2}{*}{$\begin{array}{l}\text { 罡总 } \\
\text { 总 } \\
\text { 总 }\end{array}$} & \multirow[b]{2}{*}{ 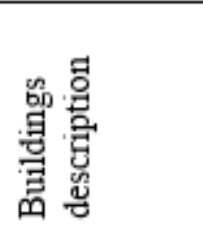 } & \multirow[b]{2}{*}{ 胥 } & \multirow{2}{*}{ 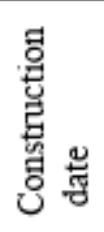 } & \multirow[b]{2}{*}{ 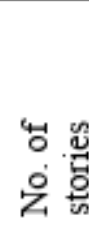 } & \multicolumn{5}{|c|}{ Story height (m) } & \multirow[b]{2}{*}{ 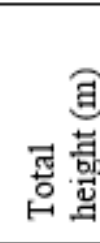 } \\
\hline & & & & & & 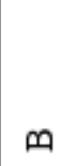 & 岁 & 岃 & 㟔 & 崫 & \\
\hline 1 & COML-06 & Commercial & Mun 6 & 2013 & 6 & 3.5 & 4.94 & 4.14 & 3.42 & 3 & 22.34 \\
\hline 2 & HB-09 & Hotel & Mun 2 & 2012 & 9 & 36.5 & 4 & 3.36 & & - & 32.8 \\
\hline 3 & RB-11 & Residential & Mun 5 & 2011 & 11 & 3 & 3 & 3 & & & 33 \\
\hline
\end{tabular}




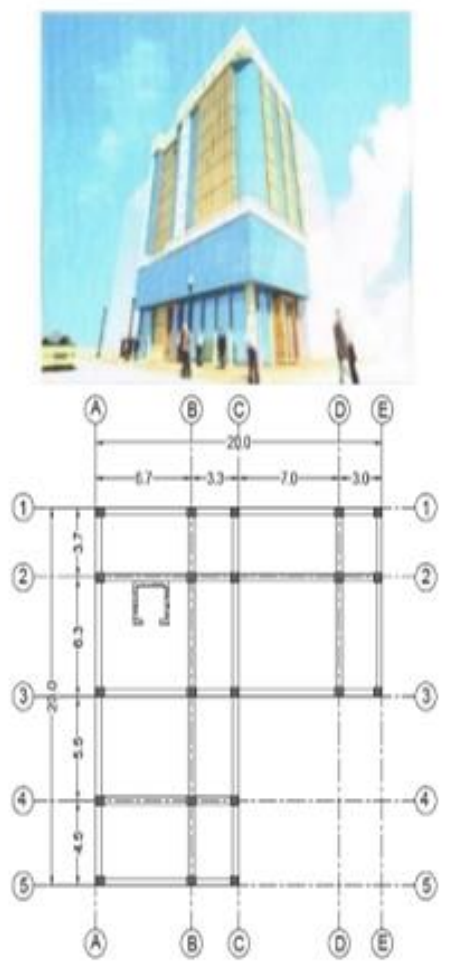

a) Commercial building

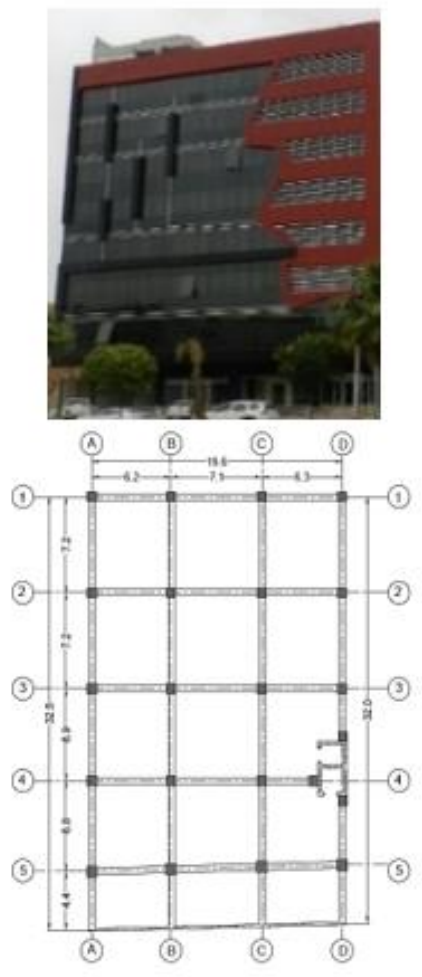

b) Hotel building

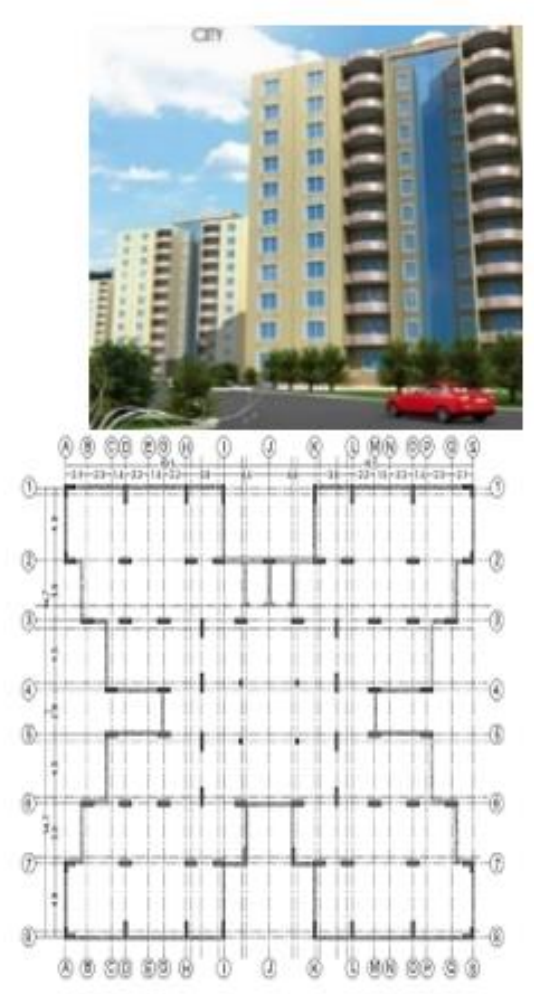

c) Residential building

Figure 2: Selected real buildings from Erbil city to represent reference buildings

\section{Ground Motion Selection}

\subsection{Selection of Compatible Ground Motions with the Seismic Characteristics in Erbil City}

Ground-motion is considered an essential component of the seismic vulnerability studies. For this purpose, seismic characteristics in Erbil city were reviewed by focusing on geology and tectonic setting, seismicity, and the previous hazard assessment (AbdulJaleel \& Taha, 2019). As a result, Abduljaleel and Taha (2019) demonstrate in their review article that the, tectonically, positioned at the north corner of the Arabian plate and classified by an outer platform of Western Zagros FoldThrust Belt. Geologically, classified by soil site class D. In addition, seismicity is characterized by strike-slip (Normal) fault, most of the earthquakes exhibit at the shallow crustal, and the maximum expected earthquake magnitude in Erbil city identified between Mw 6 and 7.5. Design PGA identified with a range of $0.4 \mathrm{~g}$ for a $2 \%$ probability of exceedance in 50 years (2475 years return period), in a term of 5\% damped at bedrock condition. Spectral acceleration also proposed with $1 \mathrm{~g}$ and $0.53 \mathrm{~g}$ at $\mathrm{S}_{\mathrm{s}}$ and $\mathrm{S}_{1}$. Consequently, ten appropriate real ground-motion records are selected by employing a web-based PEER ground-motion database and introducing four sets of ground-motion selection and modification methods, records are selected based on the important criteria including; Erbil seismic condition; defined target spectra; largest record repetitions; and different events (Abduljaleel \& Taha, 2020).

Table 2 shows a summary of the selected real records. Figure 3 compares the response spectra of the 
input ground-motion records.

Table 2: Summary of earthquake records (Abduljaleel \& Taha, 2020)

\begin{tabular}{|c|c|c|c|c|c|c|c|c|}
\hline 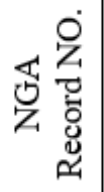 & 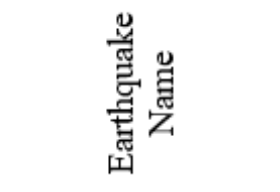 & 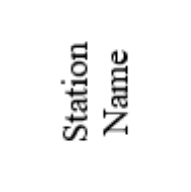 & वें & ڤ̆ & ${ }^{3}$ & 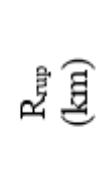 & 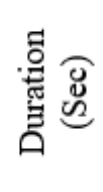 & 死 क्ञा \\
\hline 126 & "Gazli_Ussr" & "Karakyr" & GAZ000 & $\begin{array}{l}17-05- \\
1976\end{array}$ & 6.8 & 5.46 & 13.5 & 0.70 \\
\hline 183 & $\begin{array}{l}\text { "Imperial Valley- } \\
06 "\end{array}$ & $\begin{array}{l}\text { "E1 Centro } \\
\text { Array \#8" }\end{array}$ & E08140 & $\begin{array}{l}15-10- \\
1979\end{array}$ & 6.53 & 3.86 & 37.7 & 0.61 \\
\hline 5827 & $\begin{array}{l}\text { "E1 Mayor- } \\
\text { Cucapah_Mexico" }\end{array}$ & $\begin{array}{l}\text { "Michoacan } \\
\text { De Ocampo" }\end{array}$ & MDO000 & $\begin{array}{l}4-4- \\
2010\end{array}$ & 7.2 & 15.91 & 100 & 0.54 \\
\hline 8124 & $\begin{array}{l}\text { "Christchurch_New } \\
\text { Zealand" }\end{array}$ & $\begin{array}{l}\text { "Riccarton } \\
\text { High School } \\
\text { " }\end{array}$ & $86 \mathrm{~W}$ & $\begin{array}{l}21-02- \\
2011\end{array}$ & 6.2 & 17.87 & 22 & 0.29 \\
\hline 6 & $\begin{array}{l}\text { "Imperial Valley- } \\
02 "\end{array}$ & $\begin{array}{l}\text { "E1 Centro } \\
\text { Array \#9" }\end{array}$ & ELC180 & $\begin{array}{l}\text { 19-05- } \\
1940\end{array}$ & 6.95 & 6.09 & 53.7 & 0.28 \\
\hline 6893 & $\begin{array}{l}\text { "Darfield_New } \\
\text { Zealand" }\end{array}$ & "DFHSS" & $17 \mathrm{E}$ & $\begin{array}{l}03-09- \\
2010\end{array}$ & 7 & 11.86 & 150 & 0.47 \\
\hline 1602 & "Duzce_Turkey" & "Bolu" & BOL-000 & $\begin{array}{l}12-11- \\
1999\end{array}$ & 7.14 & 12.04 & 55.9 & 0.74 \\
\hline 1082 & "Northridge-01" & $\begin{array}{l}\text { "SunValley- } \\
\text { Roscoe } \\
\text { Blvd" }\end{array}$ & RO3000 & $\begin{array}{l}17-1- \\
1994\end{array}$ & 6.69 & 10.05 & 30.28 & 0.28 \\
\hline 761 & "Loma Prieta" & $\begin{array}{l}\text { "Fremont- } \\
\text { Emerson } \\
\text { Court" }\end{array}$ & FMS090 & $\begin{array}{l}18-10- \\
1989\end{array}$ & 6.93 & 39.85 & 39.7 & 0.19 \\
\hline 730 & "Spitak_Armenia" & "Gukasian" & GUK000 & $\begin{array}{l}07-12- \\
1988\end{array}$ & 6.77 & 23.99 & 20 & 0.20 \\
\hline
\end{tabular}

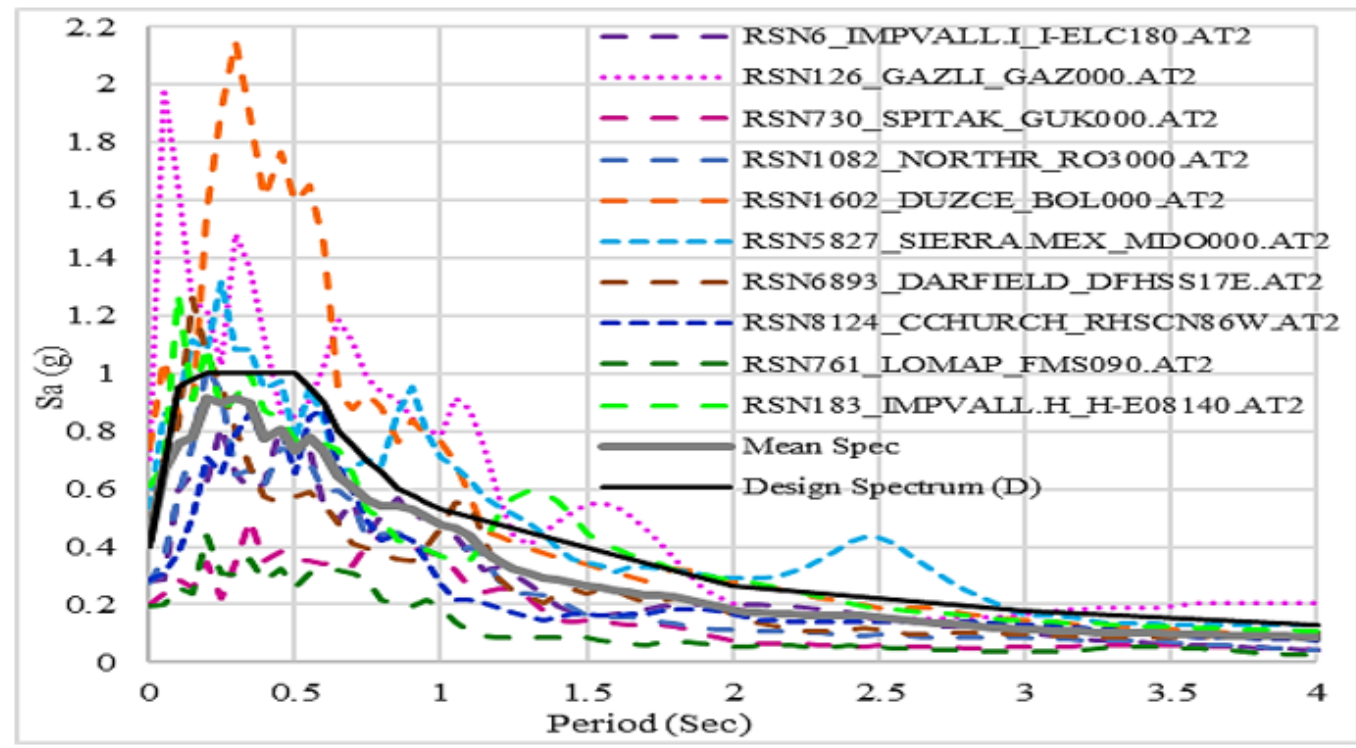

Figure 3: Response spectra of earthquake records along with their mean and response spectrum for Erbil city (Abduljaleel \& Taha, 2020) 


\subsection{Selection of Ground-Motion Intensity Measures (IM) and Damage Measures}

The possible option of ground motion IM is important for evaluating structural responses in a term of damage descriptors. Several IM were used in previous studies; Buratti (2012), Elenas (2013), Pejovic and Jankovic (2015), and Yaseen (2015) employed peak ground acceleration (PGA), peak ground velocity (PGV), peak ground displacement (PGD), spectral acceleration $(\mathrm{Sa})$, spectral velocity (Sv), and spectral displacement (Sd).

Particularly, PGA is the most popular IM which is appropriate for very stiff structures, PGV is helpful IM because the damage of several buildings is connected with energy that relies on the velocity, PGD is the maximum displacement of very flexible structures directly related to PGD. Other parameters frequency content $(\mathrm{Sa}, \mathrm{Sv}$, and $\mathrm{Sd}$ ) and earthquake duration are also affected structure behavior.

Despite challenging to choose a single scaling technique for structures with numerous dynamic properties, scaling ground-motions utilizing PGAs covers the seismic forces instantly to the input accelerations. Therefore, this basic approach argued by design codes, various studies (e.g. Ji et al. (2007) Mwafy (2012) Hassan (2014) Issa (2014)), and consequently the current study, proves to scale PGA.

\section{Structural Modeling and Analysis}

\subsection{Description of the Archetype for Reference Building Structures}

Structural elements obtained from original structural drawing plans are described below. Figure 4 depicts the generic structural plan with cross-sections of the vertical elements for the selected building including COML-06, HB-09, and RB-11, while table 3 summarizes the schedule of the horizontal elements.

\subsection{Finite Element Based Modeling}

Finite based software ETABS (https://www.csiamerica.com/products/etabs) utilized for this study to create a 3D model to idealize selected reference structures and run all the required analysis. Two different cases of finite 3D modeling analysis; bare and infilled frames are developed for reference building structures. Consequently, the members and sections modeled as follows:

1. Frame modeling

Beams and columns members modeled as frame element; section designer utilized to obtain required dimensions and reinforcements.

2. Slab modeling

Slabs are defined as area elements having the properties of shell element with the required thickness; slabs modeled as rigid diaphragm elements.

3. Shear/basement wall modeling

Shear walls and basement walls modeled as shell elements; section designer utilized to obtain required dimensions and reinforcements.

The elastic behavior of the frame and shell elements is defined by the frame and shell sections assigned to the elements. Concrete compressive strength f'c, ranges between 21 to $28 \mathrm{Mpa}$ and the reinforcing steel grade is A615 Gr60 and Gr40 with Young's modules E, 200000 Mpa, and yield- 
strength of ranges between 414 and $420 \mathrm{Mpa}$ are used for modeling.

In ETABS (CSI Computers \& Structures, 2017), nonlinear analysis can be performed using hinges. Hinges are assigned at the location of the maximum possibility of the force, for example, the maximum moment at the ends of beams and columns; with distance 0.1 and 0.9 lengths as a theoretical length adopted by code of practice. Each hinge is modeled as a discrete point hinge and represents concentrated post-yield behavior, hinges only affect the behavior of the structure in nonlinear static and nonlinear time history analysis.

Furthermore, for each degree of freedom axial and shear specified by force-displacement behavior, while bending and torsion characterized by plastic moment rotation behavior. Besides, there are three types of hinge properties in ETABS namely, user-defined nonlinear hinge properties, default hinge properties, and automated hinge properties. Automated hinge properties are calculated automatically from the frame element material and section properties, according to ACI 318-14 criteria (ACI, 2014); the material properties assigned to the frame and shell element are used to predict the plastic behavior of the hinges.

For this reason, the following types of automatic hinges are available in ETABS:

- Concrete beams in flexure (M) hinges can be generated using ASCE41-17 and using items from table 10-7.

- Concrete column in flexure (P-M-M) hinges can be generated using ASCE41-17 and using items from table 10-8 and 10-9.

- Concrete walls in flexure (P-M) fiber hinges can be generated.

Definitely, Takeda and Kinematic 's models were respectively employed to characterize the hysteretic behavior of concrete and steel materials.

Mander and Simple parametric definitions were also applied to describe stress-strain curves of concrete and steel materials, respectively. 

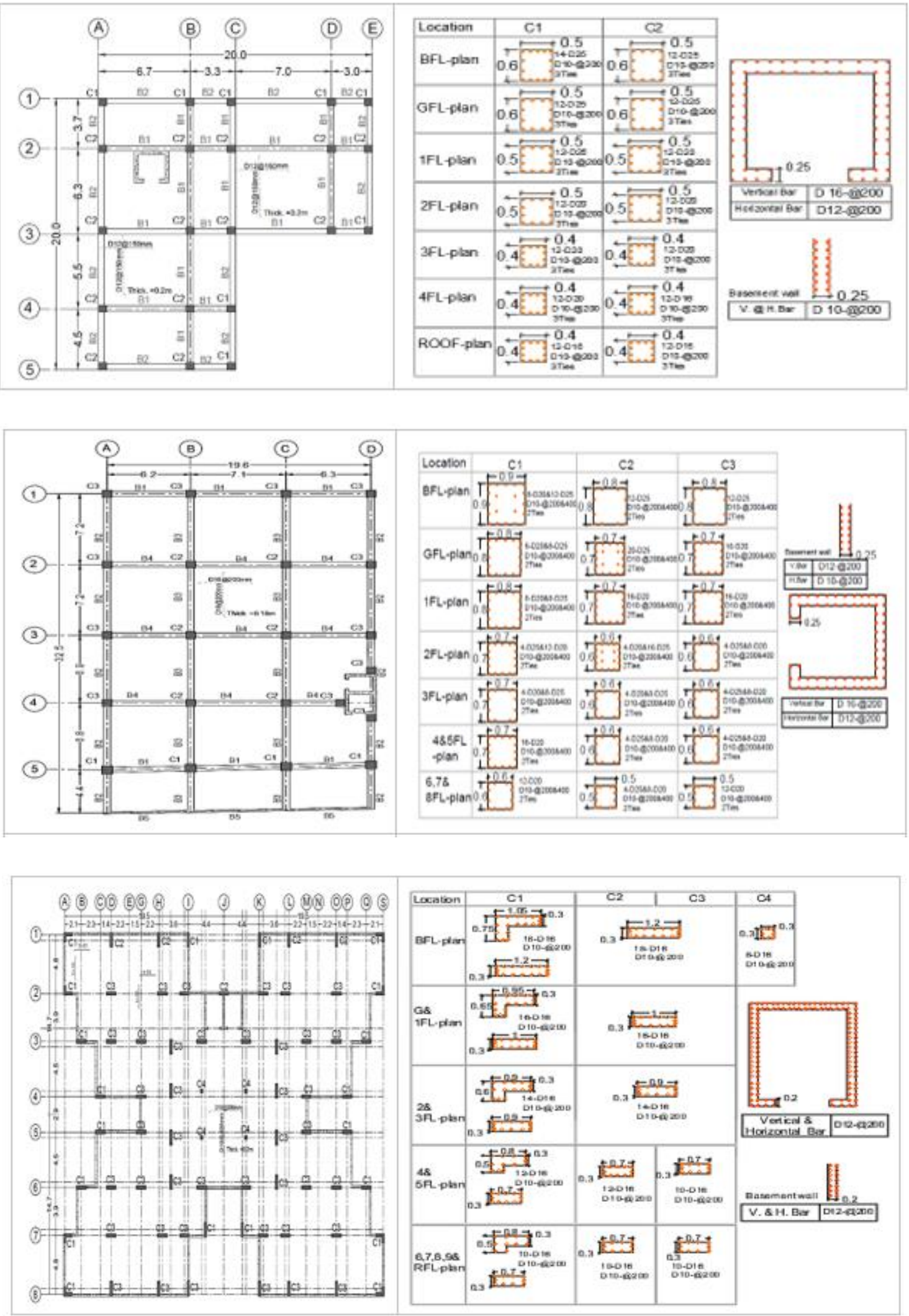

Figure 4: Generic structural plan (left) and cross-sections of the vertical members (right) for selected buildings COML-06 (top); HB-09 (middle); and RB-11 (bottom) 
Table 3: Cross-section of Beams for selected buildings

\begin{tabular}{|c|c|c|c|c|c|}
\hline FL & Beam & Size $(\mathrm{bxh}) \mathrm{mm}$ & $\begin{array}{c}\text { Top bar center } \\
\text { and end }\end{array}$ & $\begin{array}{c}\text { Bottom bar } \\
\text { center and end }\end{array}$ & Stirrup \\
\hline \multicolumn{6}{|c|}{ COML-06 } \\
\hline \multirow{2}{*}{ All } & B1 & $400 \times 600$ & $5-\mathrm{D} 20$ & $5-\mathrm{D} 20$ & D10-@200 \\
\hline & $\mathrm{B} 2$ & $400 \times 600$ & $6-\mathrm{D} 25$ & $6-\mathrm{D} 25$ & D10-@200 \\
\hline \multicolumn{6}{|c|}{ HB-09 } \\
\hline \multirow{2}{*}{ BFL } & B1 & $500 \times 650$ & 5-D20 & $5-\mathrm{D} 20$ & D10-@200 \\
\hline & B2 & $500 \times 650$ & $6-\mathrm{D} 25$ & $6-\mathrm{D} 25$ & D10-@200 \\
\hline \multirow{5}{*}{ GFL } & B1 & $500 \times 650$ & $5-\mathrm{D} 20$ & $5-\mathrm{D} 20$ & D10-@200 \\
\hline & B2 & $500 \times 650$ & 7-D20 & $6-\mathrm{D} 20$ & D10-@200 \\
\hline & B3 & $500 \times 650$ & 4-D25\&3-D20 & $6-\mathrm{D} 20$ & D10-@200 \\
\hline & B4 & $500 \times 650$ & $6-\mathrm{D} 25$ & $6-\mathrm{D} 25$ & D10@200 \\
\hline & B5 & $200 \times 650$ & $3-\mathrm{D} 20$ & $3-\mathrm{D} 20$ & D10@200 \\
\hline \multirow{5}{*}{$1 F L$} & B1 & $500 \times 650$ & 7-D20 & 7-D20 & D10@200 \\
\hline & B2 & $500 \times 650$ & $6-\mathrm{D} 25$ & $6-\mathrm{D} 25$ & D10@200 \\
\hline & B3 & $500 \times 650$ & 4-D25\& 4-D20 & $6-\mathrm{D} 20$ & D10@200 \\
\hline & B4 & $500 \times 650$ & $8-\mathrm{D} 25$ & 6-D20 & D10@200 \\
\hline & B5 & $200 \times 650$ & $3-\mathrm{D} 20$ & $3-\mathrm{D} 20$ & D10@200 \\
\hline \multirow{5}{*}{ TFL } & B1 & $500 \times 650$ & 4-D25 & $5-\mathrm{D} 20$ & D10@200 \\
\hline & $\mathrm{B} 2$ & $500 \times 650$ & $7-\mathrm{D} 25$ & $5-\mathrm{D} 25$ & D10@200 \\
\hline & B3 & $500 \times 650$ & 4-D25\&4-D20 & $5-\mathrm{D} 25$ & D10@200 \\
\hline & B4 & $500 \times 650$ & 6-D25\&3-D20 & $5-\mathrm{D} 25$ & D10@200 \\
\hline & B5 & $200 \times 650$ & $3-\mathrm{D} 20$ & $3-\mathrm{D} 20$ & D10@200 \\
\hline \multicolumn{6}{|c|}{ RB-11 } \\
\hline & All & Hidden beams & & & \\
\hline
\end{tabular}

4. Modeling equivalent strut

Usually, in the RC framed structure system, the frames are infilled with stiff construction systems, for example, brick or concrete block masonry. Masonry infilled RC frames have been popular forms of construction around the world, as well as, according to the survey of the building stock inventory, these characteristics of building structures are one of the most popular structural systems in Erbil city. Besides, the experiences in past earthquakes have observed that the presence of masonry infill walls changes the seismic response of frame building, these buildings are also more vulnerable due to vertical irregularity of the infill wall, leading to the failure of the building under the soft-story mechanism (e.g. Sharma et al. (2016) and Varum et al.(2018); Gorkha earthquake in Nepal). Therefore, for seismic vulnerability assessment of existing buildings, it is necessary considering the effect of infill walls. Infill walls modeled as an equivalent strut "compression only", unreinforced masonry block with a unit weight of $600 \mathrm{~kg} / \mathrm{m} 3$, the strength is $10 \mathrm{Mpa}$. Thickness of infill walls in outer girder with $150 \mathrm{~mm}$ (RB) and 200mm (HB and COML), while partitioning walls presence of half-thickness with about $100 \mathrm{~mm}$ in interior frames. According to the literature, various studies were modeled Infill walls as single equivalent masonry strut, the theoretical width of the diagonal strut calculated, as represented in table 4. 
Table 4: Strut width calculated by various authors

\begin{tabular}{|c|c|c|}
\hline Author & Equations & Note $(\mathrm{mm}, \mathrm{Mpa})$ \\
\hline Holmes (1961) & $\mathrm{W}=\frac{1}{3}$ Length of the panel & \multirow{5}{*}{$\begin{array}{l}\text { W: width of the diagonal compression } \\
\text { strut. } \\
\alpha \text { : Length of contact between column } \\
\text { and infill. } \\
\text { ah: Length of contact between column } \\
\text { and infill. } \\
E_{\text {me }}=\Omega \text { fm } \\
\Omega: 500 \sim 750 \\
E_{\text {me }}: \text { Young's modulus of infill } \\
\text { masonry } \\
\text { fm: Compressive strength of masonry } \\
E_{\text {fe }} \text { : young modulus of frame element } \\
I_{\text {col }} \text { : Moment of inertia of column } \\
\text { Ib: Moment of inertia of beam } \\
h_{\text {col }} \text { : Height of the column } \\
l_{\text {inf: Length of infill wall }} \\
r_{\text {inf }} \text { : Diagonal length of infill } \\
t_{\text {inf }} \text { Thickness of infill } \\
h_{\text {inf }} \text { : Height of infill } \\
\Theta: \text { Angle of the strut with horizontal }\end{array}$} \\
\hline $\begin{array}{l}\text { Smith (1966), and } \\
\text { Stafford Smith \& } \\
\text { Carter (1969) }\end{array}$ & $\begin{array}{l}\mathrm{w}=\frac{1}{2} \sqrt{\alpha \mathrm{t}^{2}+\alpha \mathrm{h}^{2}} \\
\alpha_{\mathrm{l}}=\sqrt[\frac{\pi}{2} 4]{\frac{4 \mathrm{E}_{\mathrm{fe}} \mathrm{I}_{\mathrm{col}} \mathrm{h}_{\mathrm{inf}}}{\mathrm{E}_{\mathrm{me}} \mathrm{t}_{\mathrm{inf}} \sin \theta}} \\
\alpha_{\mathrm{h}}=\sqrt[\frac{\pi}{2} 4]{\frac{4 \mathrm{E}_{\mathrm{fe}} \mathrm{I}_{\mathrm{b}} \mathrm{l}_{\mathrm{inf}}}{\mathrm{E}_{\mathrm{me}} \mathrm{t}_{\mathrm{inf}} \sin 2 \theta}}\end{array}$ & \\
\hline $\begin{array}{c}\text { Te-Chang and Kwok- } \\
\text { Hung (1984) }\end{array}$ & $\begin{array}{l}\mathrm{W}=\frac{0.95 \mathrm{~h}_{\mathrm{col}} \cos \theta}{\sqrt{\lambda \mathrm{h}_{\text {inf }}}} \\
\lambda=\left(\frac{\mathrm{E}_{\mathrm{me}} \mathrm{t}_{\text {inf }} \sin 2 \theta}{4 \mathrm{E}_{\mathrm{fe}} \mathrm{I}_{\mathrm{col}} \mathrm{h}_{\mathrm{inf}}}\right)^{0.25}\end{array}$ & \\
\hline $\begin{array}{l}\text { Paulay and Priestley } \\
\text { (1992) }\end{array}$ & $\mathrm{W}=\frac{\mathrm{r}_{\text {inf }}}{4}$ & \\
\hline $\begin{array}{l}\text { Mainstone (1971), } \\
\text { and FEMA (FEMA- } \\
356,2000)\end{array}$ & $\begin{array}{l}\mathrm{w}=0.175\left(\lambda \mathrm{h}_{\mathrm{col}}\right)^{-0.4} \mathrm{r}_{\mathrm{inf}} \\
\lambda=\left(\frac{\mathrm{E}_{\mathrm{me}} \mathrm{t}_{\mathrm{inf}} \sin 2 \theta}{4 \mathrm{E}_{\mathrm{fe}} \mathrm{I}_{\mathrm{col}} \mathrm{h}_{\text {inf }}}\right)^{0.25}\end{array}$ & \\
\hline
\end{tabular}

\subsection{Building Performance Levels}

Seismic performance principles of structures, which are described to the level of damage, have sustained centered attention. The following performance levels are considered in the seismic provisions (ASCE/SEI 41-13, 2014; ATC, 1996; FEMA-356, 2000):

1. Collapse Prevention (CP): allows for a small margin of safety against collapse during a severe earthquake.

2. Life Safety (LS): indicates significant damage to the building lateral force-resisting system but maintains a large margin against collapse.

3. Immediate Occupancy (IO): Where relatively minor damage may occur to the building, and the lateral force-resisting elements retain their initial strength and much of their original ductility.

Other performance levels have been also recommended by seismic provisions such as the operation performance (OP) criterion (ASCE/SEI 41-13, 2014). Inter-story drift ratio (IDR) is usually considered as the primary performance criterion as it is related to performance levels (ASCE/SEI 4113, 2014), several previous studies have utilized IDR to evaluate the structural damage, recommended values from previous studies summarized in table 5. 
Table 5: Review of IDRs for different limit states and structural systems

\begin{tabular}{|c|c|c|c|c|c|}
\hline \multirow{2}{*}{ Author } & \multirow{2}{*}{ Selection approach } & \multirow{2}{*}{$\begin{array}{l}\text { Structural } \\
\text { system }\end{array}$} & \multicolumn{3}{|c|}{ Inter-story drift (\%) } \\
\hline & & & IO & LS & $\mathrm{CP}$ \\
\hline \multirow{2}{*}{\multicolumn{2}{|c|}{ ASCE (ASCE/SEI 41-13, 2014) }} & RC frame & 1 & 2 & 4 \\
\hline & & RC wall & 0.5 & 1 & 2 \\
\hline \multirow{2}{*}{ Ghobarah (2004) } & \multirow{2}{*}{ Experimental } & RC frame & 0.4 & 1.8 & 3 \\
\hline & & $\mathrm{RC}$ wall & 0.4 & 1.5 & 2.5 \\
\hline Dymioties et.al. (1999) & $\begin{array}{l}\text { Experimental- } 50 \% \text { of } \\
\text { results }\end{array}$ & $\mathrm{RC}$ frame & - & - & 4 \\
\hline Lehman et al. (2013) & Experimental & RC wall & 0.5 & 1 & 2.27 \\
\hline Panagiotou et al. (2011) & Experimental & $\mathrm{RC}$ wall & 0.35 & 0.89 & 2.36 \\
\hline Beyer et al.(2008) & Experimental & $\mathrm{RC}$ wall & 0.3 & - & 2.39 \\
\hline Ramamoorthyet.al.(2008) & $\begin{array}{l}\text { Analytical- pushover } \\
\text { analysis }\end{array}$ & RC wall & 0.75 & - & 1.71 \\
\hline Kircheret.al.(1997) & $\begin{array}{l}\text { Analytical- incremental } \\
\text { dynamic analysis }\end{array}$ & $\mathrm{RC}$ wall & 0.8 & 2.3 & 6 \\
\hline Ji et. al.(2007) & Analytical pushover & $\mathrm{RC}$ frame & 0.2 & 0.52 & 1.1 \\
\hline Liel et.al.(2011) & $\begin{array}{l}\text { Analytical-incremental } \\
\text { dynamic analysis }\end{array}$ & $\mathrm{RC}$ wall & & & 4.17 \\
\hline \multirow[b]{2}{*}{ Hassan (2014) } & \multirow{2}{*}{$\begin{array}{l}\text { Analytical- pushover, } \\
\text { time history, and } \\
\text { incremental dynamic } \\
\text { analysis }\end{array}$} & RC-flat slab & 1 & 2 & 4 \\
\hline & & $\begin{array}{l}\text { RC-shear } \\
\text { wall }\end{array}$ & 0.5 & 1.135 & 2.27 \\
\hline \multirow{3}{*}{ Anas (2014) } & \multirow{3}{*}{$\begin{array}{l}\text { Analytical- pushover, } \\
\text { time history, and } \\
\text { incremental dynamic } \\
\text { analysis }\end{array}$} & $\begin{array}{l}\text { RC pre-code } \\
\text { frame }\end{array}$ & 0.39 & 1.48 & 2.96 \\
\hline & & $\begin{array}{l}\text { RC pre-code } \\
\text { wall }\end{array}$ & 0.34 & 0.89 & 1.78 \\
\hline & & $\begin{array}{l}\text { RC modern } \\
\text { frame }\end{array}$ & 1 & 2 & 4 \\
\hline
\end{tabular}

\subsection{Possible Irregularity of Structural Models}

Several real building structures are particularly irregular. Therefore, the selected models were investigated using linear static analysis so that possible irregularities of the models were verified according to the definitions of ASCE seismic code (ASCE/SEI 7-16, 2017); definitions expressed in table 6. The following results were obtained:

1. COML-06, HB-09, and RB-11 structural models (e.g. bare and infilled frame) undergo the torsional irregularity.

2. COML-06 and RB-11 structural models encounter the reentrant corner irregularity.

3. Infill walls increase the mass of models and increase the possibility of irregularity in stiffness too, it was substantially observed from COML-06, and remarked some change in RB-11, whereas slightly indicated in HB-09. 
Table 6: Vertical and horizontal irregularity criteria adopted by ASCE (ASCE/SEI 7-16, 2017)

\begin{tabular}{|l|l|l|l|}
\hline \multicolumn{1}{|c|}{ Vertical } & \multicolumn{1}{|c|}{ Criteria } & \multicolumn{1}{c|}{ Horizontal } & \multicolumn{1}{c|}{ Criteria } \\
\hline $\begin{array}{l}\text { Stiffness } / \text { soft } \\
\text { story }\end{array}$ & $\mathrm{K}_{\mathrm{i}}<70 \% \mathrm{~K}_{\mathrm{i}+1}$ or $\mathrm{K}_{\mathrm{i}}<27 \% \mathrm{~K}_{\text {ava }}$ & $\begin{array}{l}\text { Torsional } \\
\text { irregularity }\end{array}$ & $\Delta_{\operatorname{mas}}>120 \% \Delta_{\text {avg }}$ \\
\hline $\begin{array}{l}\text { Stiffness } / \text { extreme } \\
\text { soft story }\end{array}$ & $\mathrm{K}_{\mathrm{i}}<60 \% \mathrm{~K}_{\mathrm{i}+1}$ or $\mathrm{K}_{\mathrm{i}}<24 \% \mathrm{~K}_{\text {sus }}$ & $\begin{array}{l}\text { Torsional } \\
\text { irregularity/extreme }\end{array}$ & $\Delta_{\max }>140 \% \Delta_{\text {avg }}$ \\
\hline Weight (mass) & $\begin{array}{l}\mathrm{M}_{\mathrm{i}}>150 \% \mathrm{M}_{\mathrm{i}+1} \text { or } \mathrm{M}_{\mathrm{i}}>150 \% \\
\mathrm{M}_{\mathrm{i}-1}\end{array}$ & Reentrant corner & $\mathrm{L}_{\mathrm{T}}>15 \% \mathrm{~L}$ \\
\hline
\end{tabular}

\subsection{Performance Assessment of Reference Structures}

3D finite models were subjected to the following analyses were carried out by using the finite based software (ETABS) program:

\subsubsection{Free Vibration Analysis}

Eigenvalue analysis is crucial as a predecessor to dynamic analysis since the understanding of the natural frequencies and mode shapes help to present comprehensive knowledge into the dynamic response. In free vibration analysis, the stiffness and mass distribution of the structure is required to run the analysis without the application of loads, this leads to the building structures is oscillating without any external dynamic excitation (Chopra, 2012). Eigenvalue analysis conducted by Eigen modal case, considering the P-delta effect, and $90 \%$ participating modal mass as specified by ASCE (ASCE/SEI 7-16, 2017). Figure $5 \mathrm{a}, \mathrm{b}$ portray the first three modes of vibration for models and figure $5 \mathrm{c}$ shows the first three periods for the reference buildings with and without considering infill stiffness, the variation between the bare and infilled frame is confirmed by increasing stiffness in the infilled frame and shorten periods.

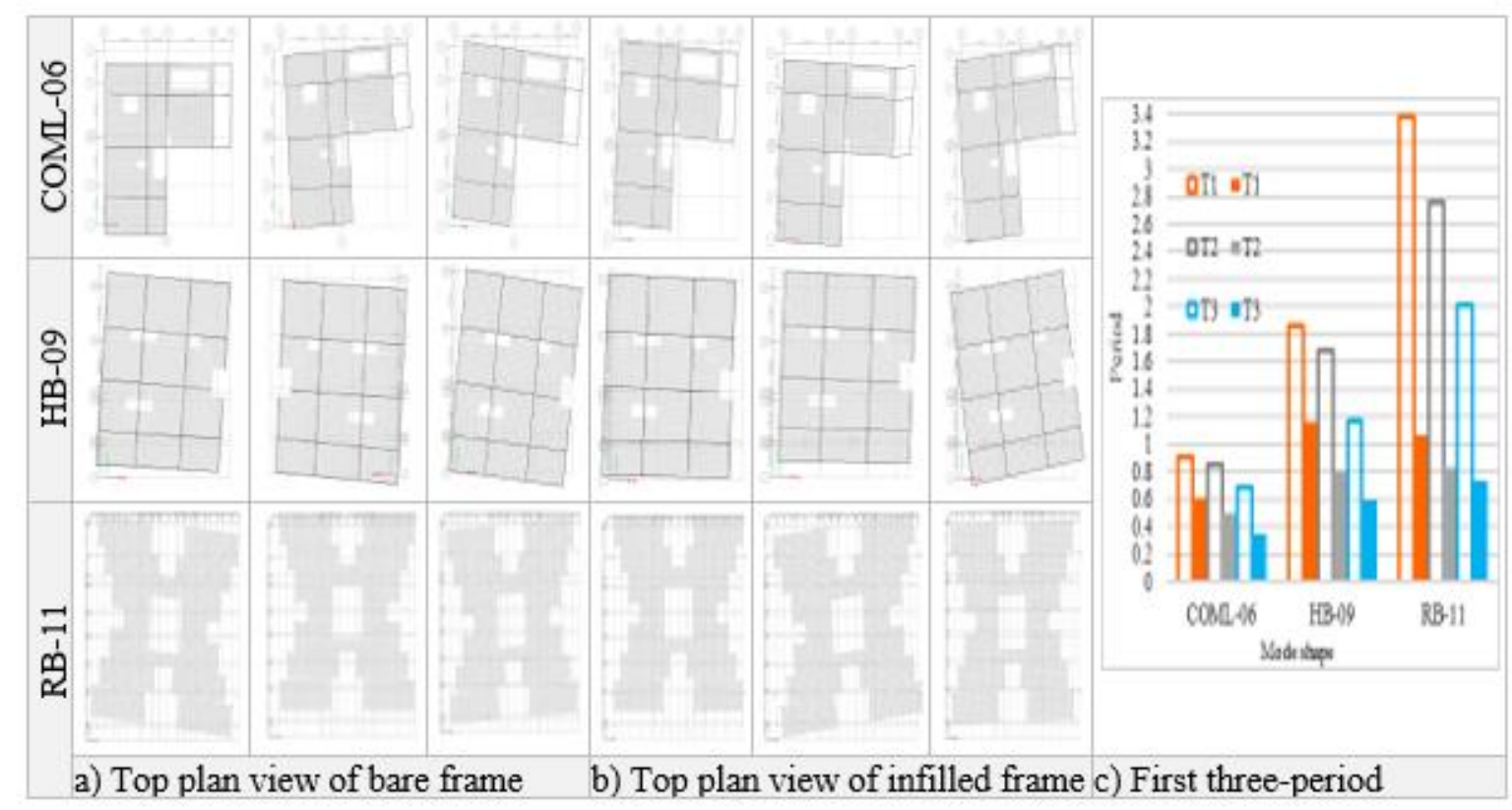

Figure 5: First three mode shapes of a) bare frame b) infilled frame c) periods, hatched pattern for infilled frame 


\subsubsection{Nonlinear Static Analysis (Inelastic Pushover Analysis)}

Nonlinear Static Analysis (NLSA) is used to evaluate the lateral capacity of a structure in the inelastic domain. This analysis comprises applying the distributed gravity load to the structure and then applying an increasing lateral load. A predetermined lateral load pattern such as uniform or inverted triangular loads is distributed throughout the building height. The analysis is conducted until a predetermined limit state or a target displacement of the structure is obtained while controlling the top displacement. With the incremental increase in the magnitude of lateral loading, probable weak areas along with failure modes of the structure can be detected. Besides, NLSA allows avoiding complex, even if rigorous, non-linear time-history analyses. Such an advantage is much more obvious by challenges associated with selection and scaling of seismic input; definition of evolutionary hysteretic models; interpretation of analysis results; and time of analysis. NLSA has been developed and verified by various authors (e.g. Gupta \& Kunnath (2000), Mwafy and Elnashai (2001) Chopra and Goel (2002), Aydinoglua (2003), Antoniou \& Pinho (2004), Hassan and Mwafy (2014), Issa and Mwafy (2014), and Khalifa and Mwafy (2015)).

Conventional pushover Capacity Spectrum Method (CSM) is conducted to the selected reference buildings to estimate the lateral strength and deformation capacity, the capacity spectrum method is employed to evaluate the seismic performance of the selected structures by intersecting the structure capacity spectrum with the response spectrum of the earthquake, according to the format of ASCE (ASCE/SEI 41-13, 2014), which was developed by Freeman (1975). Displacement controlled nonlinear analysis is conducted for the structural models by considering the important steps:

1. Suitable modeling of the building; assigning sectional reference properties.

2. Assigning gravitation loads.

3. Assigning automated hinge properties at both ends of each element beams and columns, fiber hinge is also assigned for shear walls/basement walls.

4. In the infilled model, the infill walls assigned as compression members.

5. Load case defines including; nonlinear static predefined lateral load patterns (e.g. dead load and $25 \%$ live load) representing the initial conditions for applying acceleration, then acceleration load case define at the X-direction (Push X), and acceleration load case also define at Y-direction (Push Y), by considering P-delta effects.

Nonlinear static analysis is used to verify the structural performance including the following purposes: 1) To evaluate the performance point, 2) To evaluate the distribution of inter-story drift, and 3) To evaluate the expected plastic hinges.

Performance points represented by the intersection of the capacity curve and demand curve. The lateral capacity of the structure estimated by plotting the total base shear versus top displacement and demand curves estimated by spectrum source obtained according to ASCE "PGA $=0.4 \mathrm{~g}$ for 2475 years return period" (ASCE/SEI 41-13, 2014). Figure 6 represents the capacity curve (black color), demand curve (orange color), performance point of the reference structures, and drift profiles. The detailed situation of hinges regarding the different stages of the performance level represented in table 7. 
Table 7: Hinges situation at the performance level in the selected buildings

\begin{tabular}{|c|c|c|c|c|c|c|c|c|c|}
\hline \multirow{2}{*}{$\frac{\text { Hinge }}{\text { status }}$} & \multicolumn{2}{|c|}{ Bare frame } & \multicolumn{2}{|c|}{ Infilled frame } & \multirow{2}{*}{$\begin{array}{l}\text { Hinge } \\
\text { states }\end{array}$} & \multicolumn{2}{|c|}{ Bare frame } & \multicolumn{2}{|c|}{ Infilled frame } \\
\hline & $\begin{array}{l}\mathrm{X}- \\
\text { Dir } \\
\end{array}$ & Y-Dir & X-Dir & Y-Dir & & X-Dir & Y-Dir & X-Dir & Y-Dir \\
\hline \multicolumn{10}{|c|}{ COML-06 } \\
\hline Total hinges & \multicolumn{4}{|c|}{1752} & & & & 1677 & \\
\hline Total steps & 6 & 15 & 18 & 33 & A-B & 1004 & 1010 & $10 / 7$ & 1688 \\
\hline $\begin{array}{l}\text { Performance } \\
\text { point (located } \\
\text { step) }\end{array}$ & 6 & 7 & 10 & 13 & \multirow[t]{2}{*}{ B-C } & \multirow[t]{2}{*}{148} & \multirow[t]{2}{*}{134} & \multirow[t]{2}{*}{60} & \multirow[t]{2}{*}{64} \\
\hline $\mathrm{A}-\mathrm{IO}$ & 1730 & 1744 & 1731 & 1736 & & & & & \\
\hline IO-LS & 14 & 6 & 3 & 6 & C-D & 0 & 0 & 0 & 0 \\
\hline LS-CP & 0 & 0 & 0 & 0 & D-E & 0 & 0 & 0 & 0 \\
\hline$>\mathrm{CP}$ & 8 & 2 & 18 & 10 & $>E$ & 0 & 2 & 15 & 0 \\
\hline \multicolumn{10}{|c|}{ HB-09 } \\
\hline Total hinges & \multicolumn{2}{|c|}{2565} & \multicolumn{2}{|c|}{3954} & \multirow{2}{*}{ A-B } & \multirow{2}{*}{2553} & \multirow{2}{*}{2541} & \multirow{2}{*}{3848} & \multirow{2}{*}{3818} \\
\hline Total steps & 14 & 17 & 23 & 10 & & & & & \\
\hline $\begin{array}{l}\text { Performance } \\
\text { point (located } \\
\text { step) }\end{array}$ & 1 & 1 & 2 & 4 & \multirow[t]{2}{*}{ B-C } & \multirow[t]{2}{*}{0} & \multirow[t]{2}{*}{2} & \multirow[t]{2}{*}{101} & \multirow[t]{2}{*}{116} \\
\hline A-IO & 2553 & 2543 & 3929 & 3909 & & & & & \\
\hline IO-LS & 0 & 0 & 9 & 15 & C-D & 0 & 0 & 1 & 0 \\
\hline LS-CP & 0 & 0 & 3 & 9 & D-E & 0 & 0 & 0 & 0 \\
\hline$>\mathrm{CP}$ & 12 & 22 & 13 & 21 & $>E$ & 12 & 22 & 4 & 20 \\
\hline \multicolumn{10}{|c|}{ RB-11 } \\
\hline Total hinges & \multicolumn{4}{|c|}{3866} & \multirow{2}{*}{ A-B } & \multirow{2}{*}{3756} & \multirow{2}{*}{3722} & & \\
\hline Total steps & 12 & 15 & 19 & 6 & & & & $3 / 11$ & 3822 \\
\hline $\begin{array}{l}\text { Performance } \\
\text { point (located } \\
\text { step) }\end{array}$ & 6 & 8 & 18 & 5 & B-C & 110 & 140 & 58 & 23 \\
\hline A-IO & 3854 & 3840 & 3764 & 3842 & & & & & \\
\hline IO-LS & 8 & 10 & 2 & 1 & C-D & 0 & 0 & 2 & 0 \\
\hline LS-CP & 0 & 2 & 0 & 0 & D-E & 0 & 0 & 0 & 0 \\
\hline$>\mathrm{CP}$ & 4 & 14 & 100 & 23 & $>E$ & 0 & 4 & 95 & 21 \\
\hline
\end{tabular}

According to the results of nonlinear static analysis, the following points have been discussed in the selected buildings:

1. Mapping of plastic hinges (see figure 6) showed that the level of plastic hinges reached the collapse prevention (CP) level with small limited of safety, that is showed significantly poor performance, which was reflected in the number of plastic hinges, particularly in the vertical elements, this leads to weak-column strong-beam and not in an agreement with strong -column weak-beam code concept.

2. Infill walls increase the base shear, decreasing the inter-story drift ratio, whereas, increase depicting the plastic hinges that entered the CP level, leading to the formation of the story mechanism.

3. The inadequacy seismic performance of the selected case buildings is significantly associated with the possible irregularity results, particularly, for the infilled frame, which leads to softstory and observed from the ground floor of COML-06 building. 
4. Inter-story drift ratios (IDR) at the collapse prevention (CP) is $1.24 \%, 0.67 \%$, and $1.6 \%$ for COML-06, HB-09, and RB-11 bare frame building, respectively, whereas, the IDRs at the CP is $1.16 \%, 1.27 \%$, and $0.36 \%$ for COML-06, HB-09, and RB-11 infilled frame building, respectively. It is clear from Table 5 that the CP level ranging from $2.5 \%$ to $4 \%$ is frequently used in the previous studies to define RC frame building, whereas ranging from $2 \%$ to $2.5 \%$ is frequently used for $\mathrm{RC}$ wall building, this leads to that the building height and structural system have a significant impact on the IDR. 

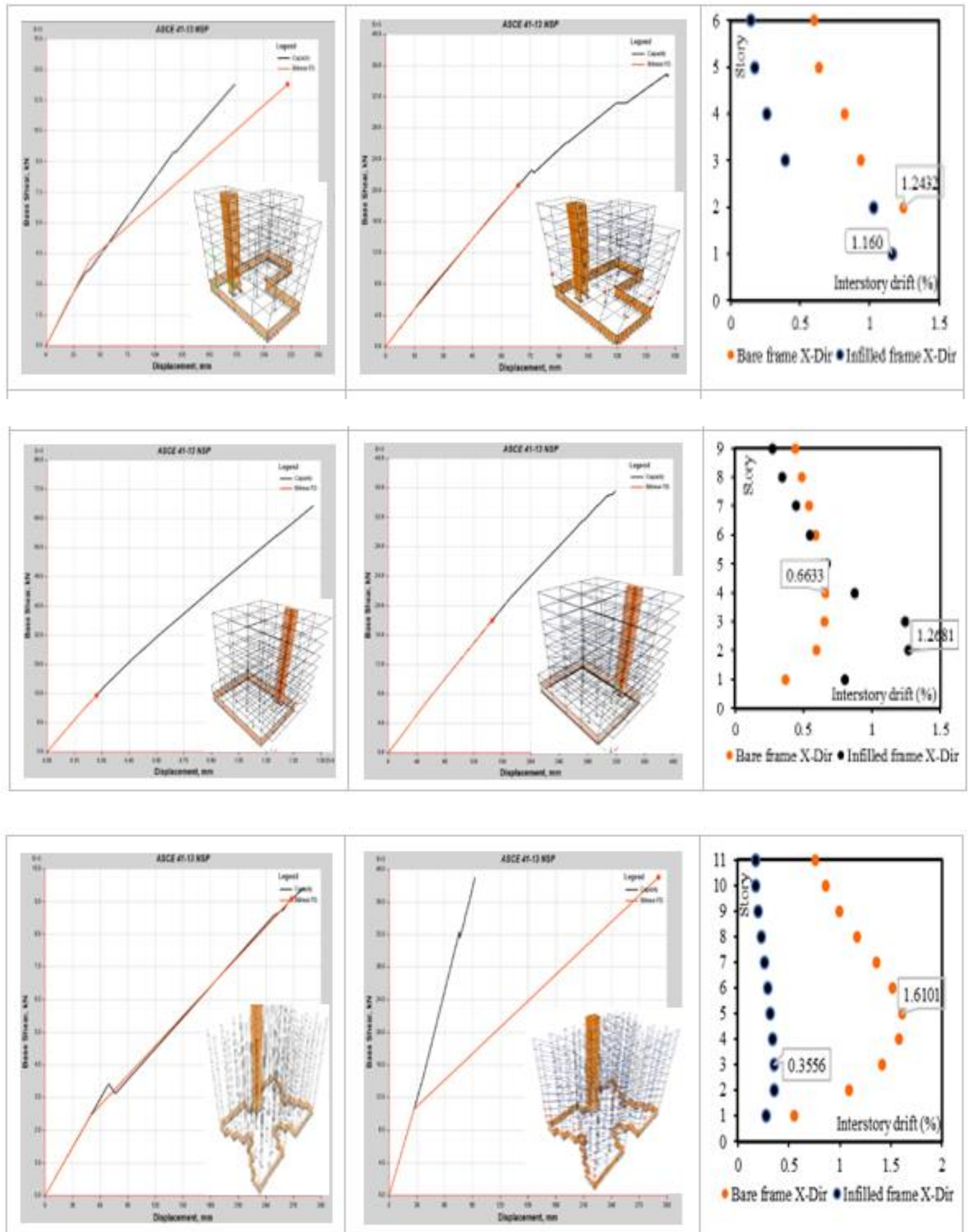

Figure 6: Capacity curves for the bare (left), infilled (right) frame, and drift profiles (end right) for buildings.

\subsubsection{Incremental Dynamic Analysis (Fast Nonlinear Analysis)}

Nonlinear Dynamic Analysis (NLDA) can generate results with high precision and relatively minimum uncertainty by utilizing the combination of ground motion acceleration. NLDA is the most 
precise and reliable approach of seismic analysis which needs high-speed computer processing and appropriate software for convenient modeling of structural elements. By analogy with passing from a single static analysis to the incremental static pushover, one enters at the extension of a single timehistory analysis into an incremental one, where ground-motion "the seismic loading" is scaled. Incremental dynamic analysis (IDA) comprises performing a series of nonlinear dynamic analyses in which the intensity of ground-motion selected for the collapse examination is incrementally increased until the global collapse capacity of the structure is attained. IDA also comprises plotting a measure of the ground motion intensity (PGA) against a response parameter such as the peak interstory drift ratio. When the slope of the IDA curve ranges from linear to nonlinear, the yield stage is considered to be attained. The collapse capacity of the structure is considered to be attained when the IDA curve converts significantly flat or the nonlinear slope becomes smaller than $20 \%$ of the elastic slope (Vamvatsikos \& Cornell, 2002). IDA is a comprehensive dynamic analysis method where the structure progresses gradually from elastic to inelastic state by incrementally increasing the hazard level.

Collapse acceleration in a unit of $\mathrm{g}$ is essentially performed to the description of the results of incremental dynamic analysis in several previous studies and the present work, Cosenza et al. (2000) evaluated the collapse acceleration with scaling one ground-motion record, whereas Bruno et al. (2000) employed the maximum results of three records to evaluate the incipient collapse conditions, whilst Tiwari and Kasnale (2017) and Rakshe and Kalwane (2018) evaluated the seismic performance based on the median collapse acceleration of nine ground-motion records, the authors also asserted the inadequacy of the structural model for the cases have less collapse acceleration (g) than the original unscaled ground-motion record.

The scaling levels are selected to force the structure throughout the entire range of behavior, from the elastic to the inelastic range and finally to collapse. To effectively utilize the incremental dynamic collapse acceleration, different scaling factors are used by previous studies; Mwafy (2012) and his students Hassan (2014), Issa (2014), and Khalifa (2015) suggested based on the seismic scenarios and building characteristic. Therefore, the selected input ground motions in the current study are scaled starting from a PGA of $0.05 \mathrm{~g}$ and ending with a PGA of $1.2 \mathrm{~g}$ or up to collapse.

Nonlinear dynamic analyses are carried out as time history Nonlinear Modal "Fast Nonlinear Analysis" using modal Ritz by considering P- $\Delta$ effects and damping ratio for all modes equal to $5 \%$, where the initial condition is defined as ramp nonlinear time history including dead load and 25\% live load. The IDA curve is plotted considering the effect of the number of time histories, a generalized IDA curve gives susceptibility prediction for a selected structural model under earthquake excitation, as illustrated in figure 7. Collapse acceleration (g) is also derived from the IDA curve for reference buildings, as depicted in Table 8.

For possible failure mechanism assessment, it was proposed that the structural model cannot sustain survive the seismic event in case the scaled PGA at the collapse is less than the original unscaled ground-motion record and the selected buildings cannot sustain any ground-motion record greater than the median collapse acceleration. As a result, the vulnerability assessment for selected reference building structures as follows:

1. Commercial (COML-06) building structure: Bare frame cannot sustain all selected records except record \#730, whereas infilled frame cannot sustain all selected records except record \#730 and \#761, based on the median value evaluation bare frame cannot sustain the ground- 
motion records (time history) larger than $0.35 \mathrm{~g}$, while infilled frame cannot sustain groundmotion records larger than $0.31 \mathrm{~g}$ (see Table 8 ). The increasing vulnerability in the infilled frame model leads to the presence of infill walls and soft-story mechanism at the ground floor and the first floor, the deficiency of the models is also confirmed by the effect of horizontal and vertical irregularities in the model.

2. Hotel (HB-09) building structure: Bare frame cannot sustain all selected records exclude record $\# 730$, \#761, and \#1082, whereas infilled frame cannot sustain record \#126, \#183, $\# 1602$, \#5827, and \#6893, depending on the median value evaluation bare frame cannot sustain the ground-motion records (time history) larger than $0.37 \mathrm{~g}$, while infilled frame cannot sustain ground-motion records larger than $0.36 \mathrm{~g}$ (see Table 8 ). The deficiency of the model under the seismic load is confirmed by the effect of horizontal and vertical irregularities in the model.

3. Residential (RB-11) building structure: Bare frame can sustain only record \#730, \#761, whereas infilled frame cannot sustain all selected records, considering the median value evaluation bare frame cannot sustain the ground-motion records larger than $0.3 \mathrm{~g}$, while the infilled frame cannot sustain ground-motion records larger than $0.17 \mathrm{~g}$ (see Table 8). The increasing vulnerability in the infilled frame model due to progressing soft story mechanism at the ground floor by conducting the nonlinear dynamic analysis, as somewhat confirmed by linear static analysis, the vulnerability of the models is also confirmed by the effect of horizontal and vertical irregularities in the model.

\subsubsection{Comparison between Inelastic Pushover and Incremental Dynamic Analysis}

Capacity curve only performed by conducting a pushover analysis so that the performance point evaluated by the intersection of the demand curve with the capacity curve as shown in figure 6 . Whereas, collapse acceleration evaluated by using an incremental dynamic analysis (IDA) curve as shown in figure 7. For the comparison purpose, the results of the max inter-story drift ratio (IDR) at the $\mathrm{CP}$ limit state calculated by pushover analysis is $1.24 \%, 0.67 \%, 1.65 \%,(1.16 \%, 1.27 \%, 0.36 \%)$ for COML-06, HB-09, RB-11 bare (and infilled) frame building. However, the average IDR obtained from the collapse IDA curve is $1.28 \%, 1.39 \%, 1.6 \%,(0.67 \%, 1.01 \%, 0.48 \%)$ for COML-06, HB-09, RB-11 bare (and infilled) frame building. As a result, the IDR results for the infilled frame have less value compared to the bare frame also adopted by previous studies (see Table 5). This is in agreement with incremental dynamic analysis results, this proves that the incremental dynamic analysis is more reliable compared with pushover analysis. 


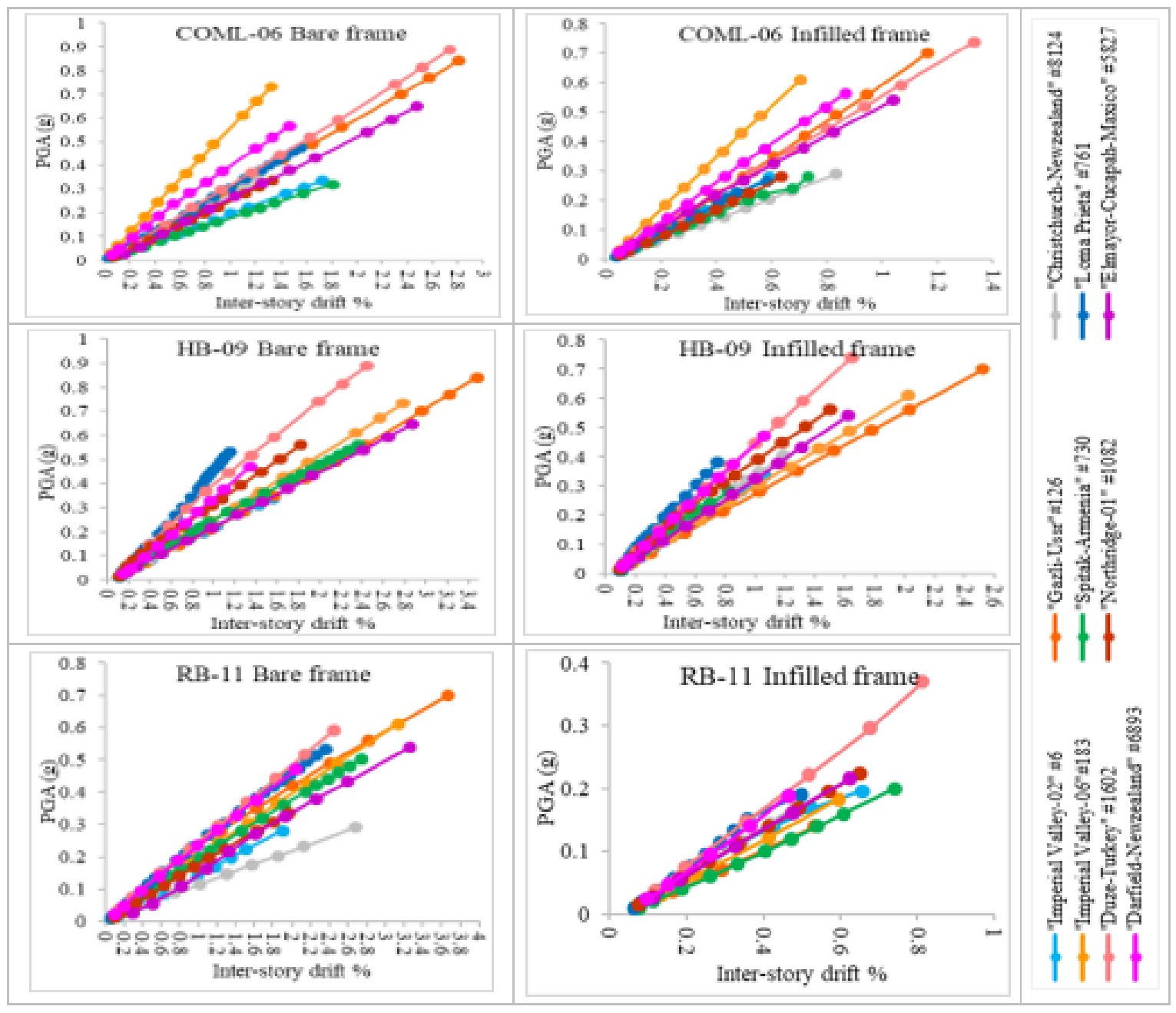

Figure 7: Incremental dynamic analysis curve for selected reference building structures

Table 8: Collapse acceleration for selected reference building structures

\begin{tabular}{|c|c|c|c|c|c|c|c|}
\hline \multirow{3}{*}{ NGA Record } & \multirow{3}{*}{$\begin{array}{c}\text { PGA } \\
\text { (g) }\end{array}$} & \multicolumn{6}{|c|}{ Collapse acceleration $(\mathrm{g})$} \\
\hline & & \multicolumn{2}{|c|}{ COML-06 } & \multicolumn{2}{|c|}{ HB-09 } & \multicolumn{2}{|c|}{ RB-11 } \\
\hline & & Bare & Infilled & Bare & Infilled & Bare & Infilled \\
\hline "Imperial Valley-02" \#6 & 0.28 & 0.22 & 0.28 & 0.22 & 0.36 & 0.06 & 0.14 \\
\hline "Gazli-Ussr"\#126 & 0.70 & 0.35 & 0.35 & 0.32 & 0.28 & 0.49 & 0.14 \\
\hline "Imperial Valley-06"\#183 & 0.61 & 0.61 & 0.37 & 0.27 & 0.27 & 0.43 & 0.12 \\
\hline "Spitak-Armenia" \#730 & 0.20 & 0.20 & 0.24 & 0.40 & 0.24 & 0.42 & 0.16 \\
\hline "Loma Prieta" \#761 & 0.19 & 0.35 & 0.23 & 0.48 & 0.38 & 0.49 & 0.19 \\
\hline "Northridge-01" \#1082 & 0.28 & 0.28 & 0.25 & 0.56 & 0.42 & 0.11 & 0.20 \\
\hline "Duze-Turkey" \#1602 & 0.74 & 0.44 & 0.37 & 0.44 & 0.52 & 0.37 & 0.22 \\
\hline $\begin{array}{l}\text { "Elmayor-Cucapah-Maxico" } \\
\# 5827\end{array}$ & 0.54 & 0.27 & 0.32 & 0.32 & 0.35 & 0.11 & 0.16 \\
\hline "Darfield-Newzealand" \#6893 & 0.47 & 0.47 & 0.47 & 0.42 & 0.42 & 0.19 & 0.19 \\
\hline $\begin{array}{l}\text { "Christchurch-Newzealand" } \\
\# 8124\end{array}$ & 0.29 & 0.32 & 0.26 & 0.29 & 0.38 & 0.29 & 0.15 \\
\hline Median & & 0.35 & 0.31 & 0.37 & 0.36 & 0.30 & 0.17 \\
\hline
\end{tabular}




\section{Conclusions}

The central objective of this study is to investigate the seismic vulnerability of the existing inventory in Erbil city in response to the future anticipated earthquake. The selected building structures subjected to a sequence of Eigenvalue analyses, NLSA, and IDA to assess their dynamic characteristics, lateral capacities, and seismic performance. The following conclusions are summarized below:

1. It was observed that the Eigenvalue results validate the numerical models and assist value in the results obtained from the present study. Besides, the discrepancies between the dynamic characteristics obtained from the bare and infilled frame, these differences were justified by increasing stiffness in the infilled frame and shorten periods.

2. The important results of the pushover for the selected reference buildings indicated that the demand curve intersects the capacity curve with limited reserve of strength and deformation capacity, this means that the selected reference structures have poor performance under the earthquake, and more vulnerable for seismic excitation.

3. The expected PGA value was identified by $0.4 \mathrm{~g}$ for 2475 years return period. Consequently, the seismic strength for selected reference building structures concluded as follows by performing the incremental dynamic analysis:

- Commercial (COML-06) building structure: It was indicated that the capacity of the bare frame COML-06 building structure with the dynamic analysis is ineffective, the strength is $0.35 \mathrm{~g}$. Whereas, the presence of infilling masonry walls increases the vulnerability corresponding to collapse condition is in the order of $0.30 \mathrm{~g}$.

- Hotel (HB-09) building structure: It was specified that the capacity of the HB-09 building structure with the dynamic analysis is ineffective, the strength is roughly about $0.35 \mathrm{~g}$. The bare and infilled frame almost has the same effect.

- Residential (RB-11) building structure: It was marked that the capacity of the bare frame RB-11 building structure with the dynamic analysis is ineffective, the corresponding to collapse conditions does not exceed $0.3 \mathrm{~g}$. Whereas, the presence of infilling masonry walls increases the vulnerability into roughly twice.

4. Significantly, infill walls have influenced on the performance evaluation, it was noted that the infilled frame is more vulnerable for the seismic than the bare frame, due to stiffness irregularity in the vertical direction.

5. It was noted that the infilled frames have fewer drift ratios than the bare frame.

6. Mapping of plastic hinges showed that the first indication was observed in the vertical member, this leads to weak-column strong-beam and not in an agreement with a strongcolumn week-beam code concept.

7. It was concluded that the results obtained by the incremental dynamic analysis approach are more accurate than the static pushover analysis.

8. The results indicated the urgent need for seismic retrofit for the selected reference building structures to reduce their seismic losses.

\section{Reference}

AbdulJaleel, Z. A., \& Taha, B. O. (2019). Review of Seismic Characteristics in Erbil City, the Capital of the Kurdistan Region of Iraq. Polytechnic Journal, 9(2), 161-170.

Abduljaleel, Z. A., \& Taha, B. O. (2020). Selection of Compatible Ground Motions with the Seismic Characteristics of Erbil City, the Capital of the Kurdistan Region of Iraq. Polytechnic 
Journal, 10(1), 110-120.

ACI, A. C. (2014). Building Code Requirements for Structural Concrete (ACI 318-14): Commentary on Building Code Requirements for Structural Concrete (ACI 318R-14): an ACI Report. American Concrete Institute. ACI.

Antoniou, S., \& Pinho, R. (2004). Advantages and Limitations of Adaptive and Non-Adaptive ForceBased Pushover Procedures. Journal of Earthquake Engineering, 8(04), 497-522.

ASCE/SEI 7-16. (2017). Minimum Design Loads and Associated Criteria for Buildings and Other Structures.

ASCE/SEI 41-13. (2014). Seismic Evaluation and Retrofit of Existing Buildings.

ATC. (2011). Seismic Performance Assessment of Buildings Volume 1 - Methodology ATC-58-1 75\% Draft. Applied Technology Council, Redwood City, California 94065.

ATC, A. T. (1996). Evaluation and Retrofit of Concrete Buildings, Rep. ATC-40, Applied Technology Council, Redwood City, California.

Aydinoğlu, M. N. (2003). An Incremental Response Spectrum Analysis Procedure Based on Inelastic Spectral Displacements for Multi-Mode Seismic Performance Evaluation. Bulletin of Earthquake Engineering, 1(1), 3-36.

Beyer, K., Dazio, A., \& Priestley, M. J. N. (2008). Quasi-static Cyclic Tests of Two U-shaped Reinforced Concrete Walls. Journal of Earthquake Engineering, 12(7), 1023-1053.

Bruno, S., Decanini, L., \& Mollaioli, F. (2000). Seismic Performance of Pre-Code Reinforced Concrete Buildings. Proc. 12th WCEE.

Buratti, N. (2012). A Comparison of the Performances of Various Ground-motion Intensity Measures. The 15th World Conference on Earthquake Engineering, Lisbon, Portugal, 24 28.

Chopra, A. K. (2012). Dynamics of Structures, 4th. New Jersey: Prentice Hall.

Chopra, A. K., \& Goel, R. K. (2002). A Modal Pushover Analysis Procedure for Estimating Seismic Demands for Buildings. Earthquake Engineering \& Structural Dynamics, 31(3), 561-582.

Cosenza, E., Manfredi, G., \& Verderame, G. (2000). Seismic Assessment of RC Structures: Case Studies in Catania. The Catania Project: Earthquake Damage Scenario for a High Risk Area in the Mediterranean. Gruppo Nazionale per La Difesa Dai Terremoti^ CNR, Roma.

CSI Computers, \& Structures, I. (2017). CSI Analysis Reference Manual for SAP2000, ETABS, SAFE, and CSiBridge. CSI Berkeley, CA.

CSO. (2011). Central Statistical Organization, Buildings, Housing and Households-Central Bureau of Statistics (Buildings, Dwellings, and Households-Erbil Governorate; $\mathrm{p}$. (http://maincosit.gov.iq/ar/pop-/enumerating2009?id=366)).

Dymiotis, C., Kappos, A. J., \& Chryssanthopoulos, M. K. (1999). Seismic Reliability of RC Frames with Uncertain Drift and Member Capacity. Journal of Structural Engineering, 125(9), $1038-1047$.

Elenas, A. (2013). Intensity Parameters as Damage Potential Descriptors of Earthquakes. In Computational Methods in Stochastic Dynamics (pp. 327-334). Springer.

FEMA-356, B. S. S. (2000). Prestandard and Commentary for the Seismic Rehabilitation of Buildings. Report FEMA-356, Washington, DC.

Freeman, S. A. (1975). Evaluations of Existing Buildings for Seismic Risk-A Case Study of Puget Sound Naval Shipyard. Proc. 1st US Nat. Conf. on Earthquake Engrg., Bremerton, Washington, 1975, 113-122.

Ghobarah, A. (2004). On Drift Limits Associated with Different Damage Levels. International Workshop on Performance-Based Seismic Design, 28.

Gupta, B., \& Kunnath, S. K. (2000). Adaptive Spectra-based Pushover Procedure for Seismic Evaluation of Structures. Earthquake Spectra, 16(2), 367-392.

Hassan, A. A. A. A., \& Mwafy, A. (2014). Vulnerability Functions for Seismic Loss Assessment of the Modern Multi-Story Buildings in Dubai. [MSc thesis]. United Arab Emirates Unversity.

Holmes, M. (1961). Steel Frames with Brickwork and Concrete Infilling. Proceedings of the Institution of Civil Engineers, 19(4), 473-478. 
IMOS. (2018). Iraqi Meteorological Organization and Seismology. www.meteoseism.gov.iq.com Ismaeil, M. (2018). Seismic Capacity Assessment of Existing RC Building by Using Pushover Analysis. Civil Engineering Journal, 4(9), 2034-2043.

Issa, A., \& Mwafy, A. (2014). Development of Simulation-Based Fragility Relationships for the Seismic Risk Assessment of Buildings [MSc thesis]. United Arab Emirates Unversity. Ji, J., Elnashai, A. S., \& Kuchma, D. A. (2007). An Analytical Framework for Seismic Fragility Analysis of RC High-Rise Buildings. Engineering Structures, 29(12), 3197-3209.

Khalifa, A., \& Mwafy, A. (2015). Assessment of Multi-story Building Seismic Design Factors with Structural Irregularity.

Kircher, C. A., Nassar, A. A., Kustu, O., \& Holmes, W. T. (1997). Development of Building Damage Functions for Earthquake Loss Estimation. Earthquake Spectra, 13(4), 663-682.

KRSO. (2018). Kurdistan Region Statistics Office, the Report of the Census Result 2009-Report No.1-Erbil Governorate-Buildings, Dwellings, and Households, http://www.krso.net/Default.aspx?page=article [KRG/Erbil]. Latest Publication, Erbil Map.

Lehman, D. E., Turgeon, J. A., Birely, A. C., Hart, C. R., Marley, K. P., Kuchma, D. A., \& Lowes, L. N. (2013). Seismic Behavior of a Modern Concrete Coupled Wall. Journal of Structural Engineering, 139(8), 1371-1381.

Liel, A. B., Haselton, C. B., \& Deierlein, G. G. (2011). Seismic Collapse Safety of Reinforced Concrete Buildings. II: Comparative Assessment of Nonductile and Ductile Moment Frames. Journal of Structural Engineering, 137(4), 492-502.

Mainstone, R. J. (1971). Summary of Paper 7360. On the Stiffness and Strengths of Infilled Frames. Proceedings of the Institution of Civil Engineers, 49(2), 230.

Mwafy, A. (2012). Analytically Derived Fragility Relationships for the Modern High-rise Buildings in the UAE. The Structural Design of Tall and Special Buildings, 21(11), 824-843.

Mwafy, A. M., \& Elnashai, A. S. (2001). Static Pushover Versus Dynamic Collapse Analysis of RC Buildings. Engineering Structures, 23(5), 407-424.

Occhipinti, G., Caliò, I., Izzuddin, B., \& Macorini, L. (2017). Seismic Assessment and Rehabilitation of Existing RC Buildings not Designed to Withstand Earthquakes [PhD Thesis]. University of Catania.

Panagiotou, M., Restrepo, J. I., \& Conte, J. P. (2011). Shake-table Test of a Full-scale 7-Story Building Slice. Phase I: Rectangular Wall. Journal of Structural Engineering, 137(6), 691-704.

Paulay, T., \& Priestley, M. N. (1992). Seismic Design of Reinforced Concrete and Masonry Buildings. John Wiley and Sons.

Pejovic, J., \& Jankovic, S. (2015). Selection of Ground Motion Intensity Measure for Reinforced Concrete Structure. Procedia Engineering, 117(1), 588-595.

Presidency of Erbil Municipality. (2012). Presidency of Erbil Municipality, GIS part, Municipalities Boundary Image (jpg), June 2018. Unpublished, June 2018.

Rakshe, R., \& Kalwane, U. (2018). Incremental Dynamic Analysis and Static Pushover Analysis of Existing RC Framed Buildings Using The Seismostruct Software. International Journal of Advance Research, Ideas and Innovations in Technology, 4(2), 2088-2101.

Ramamoorthy, S. K., Gardoni, P., \& Bracci, J. M. (2008). Seismic Fragility and Confidence Bounds for Gravity Load Designed Reinforced Concrete Frames of Varying Height. Journal of Structural Engineering, 134(4), 639-650.

Sharma, K., Deng, L., \& Noguez, C. C. (2016). Field Investigation on the Performance of Building Structures During the April 25, 2015, Gorkha earthquake in Nepal. Engineering Structures, 121, 61-74.

Smith, B. S. (1966). Behavior of Square Infilled Frames. Journal of the Structural Division, 92(1), 381-404.

Stafford Smith, B., \& Carter, C. (1969). A Method of Analysis for Infilled Frames. Proceedings of the Institution of Civil Engineers, 44(1), 31-48.

Te-Chang, L., \& Kwok-Hung, K. (1984). Nonlinear Behaviour of Non-integral Infilled Frames. 
Computers \& Structures, 18(3), 551-560.

Tiwari, V., \& Kasnale, A. (2017). Incremental Dynamic Analysis of RC Frames. International Research Journal of Engineering and Technology, 4(2), 697-700.

Vamvatsikos, D., \& Cornell, C. A. (2002). Incremental Dynamic Analysis. Earthquake Engineering \& Structural Dynamics, 31(3), 491-514.

Varum, H., Dumaru, R., Furtado, A., Barbosa, A. R., Gautam, D., \& Rodrigues, H. (2018). Seismic Performance of Buildings in Nepal After the Gorkha Earthquake. In Impacts and Insights of the Gorkha Earthquake (pp. 47-63). Elsevier.

Yaseen, A. A. (2015). Seismic Fragility Assessment of Masonry Buildings in the Kurdistan Region [PhD Thesis]. University of Portsmouth. 